\title{
Engineering Geological Assessment for Route Selection of Railway Line in Geologically Active Area: A Case Study in China
}

\author{
HUANG Run-qiu' ${ }^{*}$, LI Yan-rong², QU Ke3, WANG Ke3 \\ 1 State Key Laboratory of Geohazard Prevention and Geoenvironment Protection, Chengdu University of Technology, \\ Chengdu 610059, China \\ 2 AGECON Ltd., Hong Kong 852, China (e-mail: li.dennis@hotmail.com) \\ 3 The Second Survey and Design Institute of China Railways, Chengdu 610o31, China
}

*Corresponding author, e-mail: hrq@cdut.edu.cn

(C) Science Press and Institute of Mountain Hazards and Environment, CAS and Springer-Verlag Berlin Heidelberg 2013

\begin{abstract}
The Cheng-Lan railway links Chengdu, a central city in Southwestern China, and Lanzhou, a central city in Northwestern China. The railway passes through the Longmenshan fault zone (Wenchuan earthquake happened there on May 12, 2008), Minjiang fault zone, and Dongkunlun fault zone, which are all active. It runs over the Yangtze River and the Yellow River, and crosses high mountains and deep valleys. There exists, along the railway's alignment, different kinds of strata of hard granite and soft, weak metamorphic rocks such as carbonaceous slate, schist, and phyllite. It is, therefore, a key issue for such an infrastructure construction to assess the engineering geological conditions and risks, so as to mitigate or avoid possible georisks and to offer optional designs. Geological survey and georisk assessment along the railway corridor are carried out. Special attention is given to active faults, earthquakes and seismic zones. Based on these, discussions about geological aspects for route selection of the railway are conducted and countermeasures for georisk control are proposed accordingly. Main conclusions are achieved as follows: (1) Geohazards such as landslides, rockfalls and debries flows dominate both the route selection of the railway and the engineering structures (e.g., tunnels or bridges) adopted; (2) Tunnel has been proved to be an excellent structure for linear engineering in geologically active area; and (3) In the case where avoiding is impractical, necessary protection measures should be taken to engineering slopes in high earthquake intensity areas, especially the area with earthquake of Ms. 8 or greater.
\end{abstract}

Received: 22 February 2013

Accepted: 24 May 2013
Keywords: Railway route selection; Geologically active area; Earthquake; Active fault

\section{Introduction}

Active tectonic regions are widely spread, especially along the margin of plates. Engineering construction in such regions meets a series of problems related with tectonic activity directly or indirectly. Continuous fault activities, for instance, lead engineering facilities to fail. It is also possible that earthquake-induced landslides and soil liquefaction, and frozen soils threaten the safety of engineering structures. This is also the reason that active tectonic regions are considered to be of high risk (Li et al. 2012; Gao et al. 2012; Chen and Li 2006).

Western china, especially the Tibetan Plateau quickly uplifted due to intensive collision between the Indian Plate and Eurasia Plate since Himalaya was formed. Extrusion between the Tibetan Plateau plate and rigid Yangtze platform forces the crust thickness to change rapidly ( $\mathrm{Li}$ et al. 2003). This region is characterized by marked tectonic activities and strong earthquakes. The altitude varies from $1,500 \mathrm{~m}$ to $4,500 \mathrm{~m}$ in this region, where several major rivers are running, such as the Yangtze River, Minjiang River, Yalong River, Dadu River, Lantsang River and Nu River.

In recent years China government devoted 
much fund to the Western Development Strategy. Traffic network linking Western China to other areas is one of the important components of this strategy. Many modern infrastructures have been finished, such as Qingzang (Qinghai-Tibet) railway (Du et al. 2012). With further implementation of the Western Development Strategy, it is inevitable that the linearly stretching civil engineering like railway has to pass through the extremely active tectonic regions. Studies in this dependency have been widely conducted for the Dali-Ruili railway by Zhou and $\mathrm{Wu}$ (2012) and the Kun-He railway by Qing et al. (2006).

The Cheng-Lan railway, with a length of $457.59 \mathrm{~km}$ starts from Chengdu (see Figure 1) and runs through cities, Guanghan, Shifang, Mianzhu, Maoxian, Songpan and Jiuzhaigou, towards Hadapu to get connected with Lan-Yu Railway (linking Lanzhou and Chongqing). This railway line together with the finished BaoCheng (Baoji-Chengdu) railway, the under-constructed Lan-Yu line will form a developed railway network connecting the northwest to southwest of China.

The Cheng-Lan railway discussed in the paper will work as an important branch of the national traffic network. As shown in Figure 1, this railway starts at an elevation of about $500 \mathrm{~m}$ above sea level, runs northwards through the Longmenshan mountain, and climbs up to the east of the Tibetan Plateau at an elevation of $3,500 \mathrm{~m}$. After that, it crosses watershed mountains between

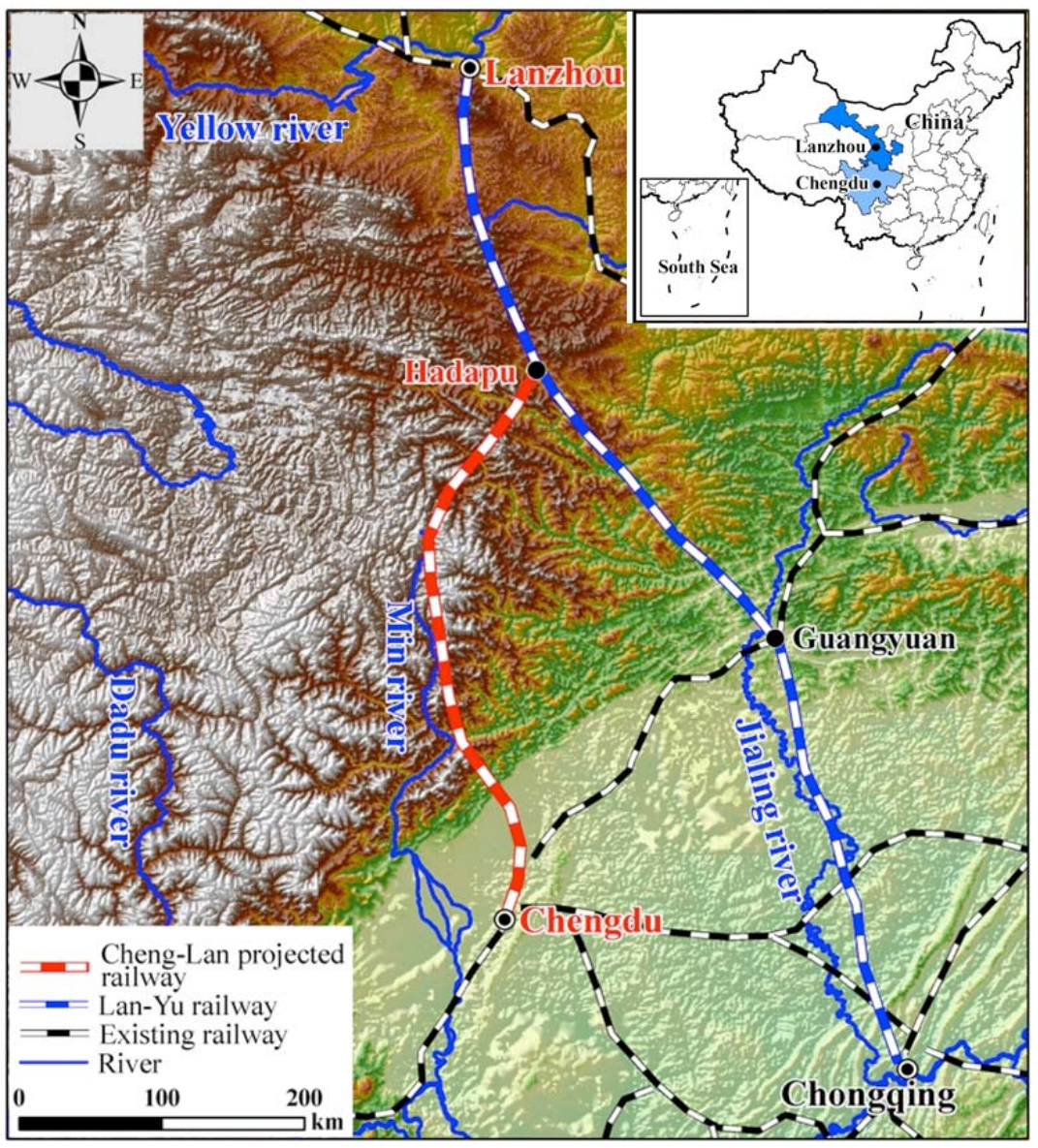

Figure 1 Layout of the Cheng-Lan railway

the Yangtze River and the Yellow River, and finally reaches Lanzhou City at an elevation of $1,500 \mathrm{~m}$. The railway line passes through three fault zones, i.e., the Longmanshan, Minjiang, and Dongkunlun. Hard granite is exposed along the railway line, and many outcrops exhibit metamorphic strata including carbonaceous slate, schist, and phyllite. Landslides induced by the 2008 Wechuan earthquake make the above-mentioned geological environment even worse. The region where the railway stretches over is classified as active geological area with high georisk. It is, therefore, a key issue to properly and correctly assess the engineering geological condition along the railway corridor, in order to minimize risks, and to offer a rational railway location and optional designs.

\section{General Engineering Geological Condition}

\subsection{Geomorphology}

There exist high mountains and canyons in the planning region, as shown in Figure 2. The elevation of the Chengdu basin ranges from 500 to $700 \mathrm{~m}$ above sea level, and the elevation of the Tibetan Plateau varies from 3,000 to $5,600 \mathrm{~m}$ (Li et al. 2003). The relative height difference of the landform along the railway line is normally more than 1000 $\mathrm{m}$, and about $200 \mathrm{~km}$ of the railway segments are located in 
the region with a relative height difference of about $3000 \mathrm{~m}$. In general, the terrain is usually high at the northwest and low at the southeast.

\subsection{Stratigraphy}

The age of strata exposed along the railway corridor varies from the Sinian to the Quaternary. The lithology covers magmatic, sedimentary and metamorphic rocks. About 70\% of the rocks along the railway line are soft and broken slate, carbonaceous slate, schist and phyllite.

\subsection{Tectonic structure}

The Cheng-Lan railway has to go through three major tectonic zones, the NE-striking Longmenshan fault zone, West Qinling fault zone, and nearly SN-striking Minjiang fault zone, which make up an "A" form as shown in Figure 3 . The Longmenshan fault zone at the eastern boundary of the Tibetan Plateau is a geologically active zone with a strong earthquake history.

\subsection{Engineering geological condition}

Since the Late Cenozoic, large-scale horizontal shear movements have formed in the east of Tibetan Plateau, along with rapid uplifting of the Tibetan Plateau and the eastward creeping motion of crustal material (Figure 3). This makes the deep faults active. The engineering geology, along the Cheng-Lan railway, is generally characterized by high

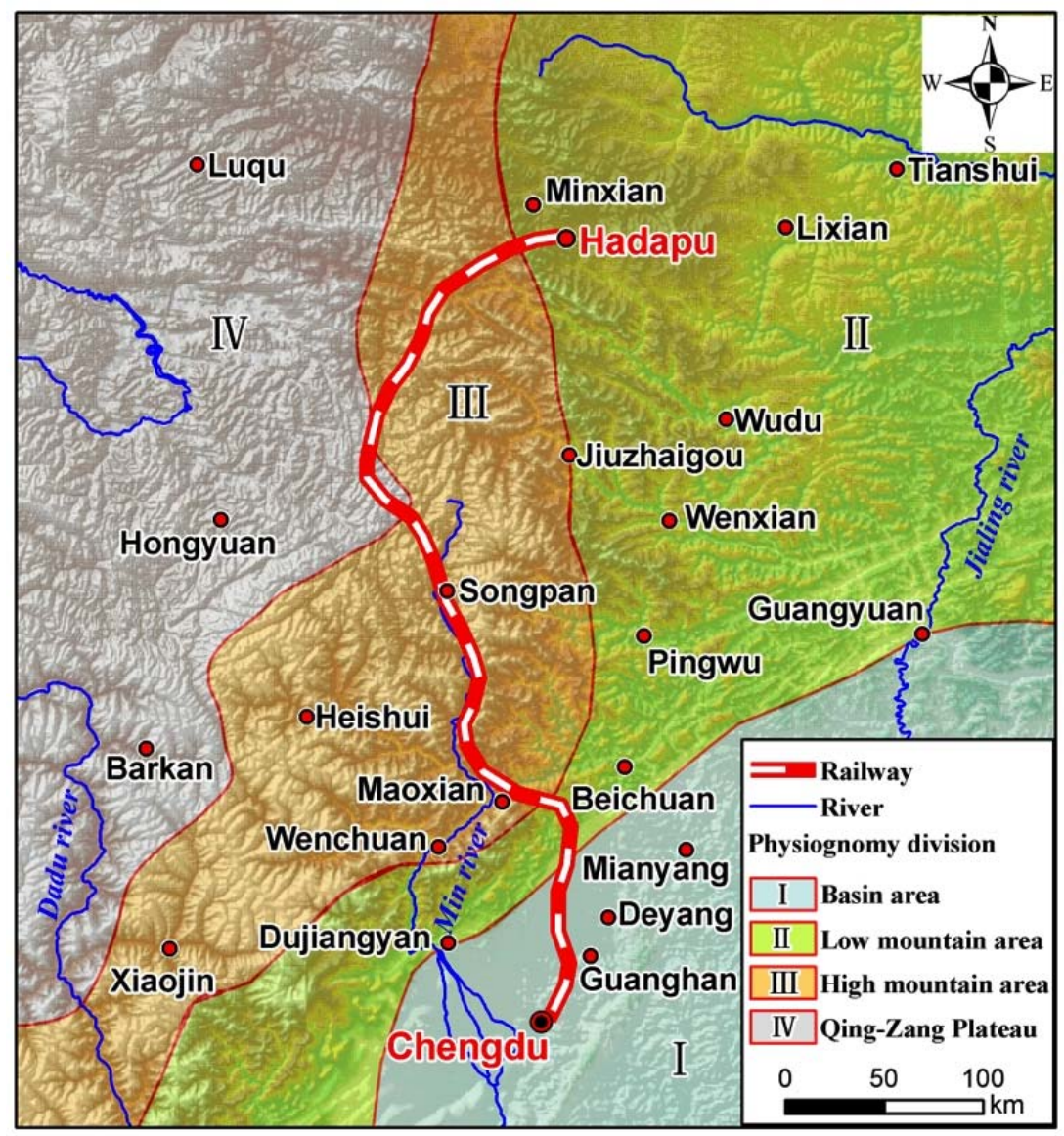

Figure 2 Landform of the study area

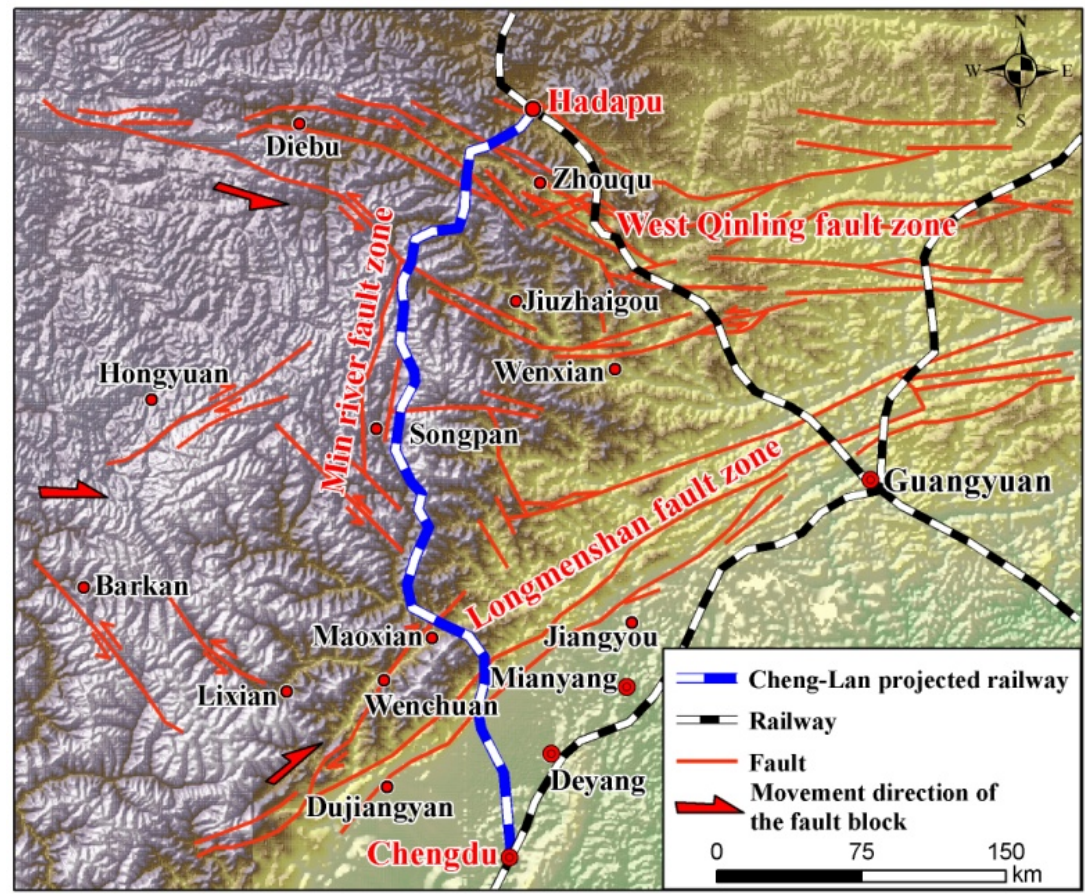

Figure 3 Structure sketches in the study area 
geostress, great earthquake intensity and high sensitivity to geohazards, such as landslide, debris flow and unstable slope.

\section{Assessment of Engineering Geological Conditions and Proposed Measures for Georisk Control}

\subsection{Active fault}

As stated in previous sections, the Cheng-Lan railway runs through three active fault zones, i.e., the Longmenshan fault zone, Minjiang fault zone and West Qinling fault zone, which involve eleven faults of different scales as shown in Figure 3. The Longmenshan fault zone is made up of three main faults, which are Pengxian-Guanxian, BeichuanYingxiu and Maowen-Wenchuan faults (Figure 4). All of them are active since the Late Quaternary. The Longmenshan fault zone is about $30-40 \mathrm{~km}$ wide and 500 $\mathrm{km}$ long, with the strike direction of $\mathrm{N} 40-50^{\circ} \mathrm{E}$. The Beichuan-Yingxiu fault and Pengxian-Guanxian fault are the seismogenic structures of Ms. 8.0 Wenchuan earthquake in 2008, which have caused great surface dislocation. The Ms. (magnitude scale) is according to Standard GB/T 17742-1999.

The Pengxian-Guanxian fault is typical of thrust fault with the strike of $\mathrm{N}_{50} \mathrm{O}^{\circ} \mathrm{E}$ and dips ranging from $24^{\circ}$ to $65^{\circ}$ ( $\mathrm{F}_{3}$ in Figure 4). It is mainly developed among the Xujiahe formation $\left(\mathrm{T}_{3 \mathrm{x}}\right)$. The surface ruptures, with a total length of about $100 \mathrm{~km}$, occurred along PengxianGuanxian fault during the 2008 Wenchuan earthquake.

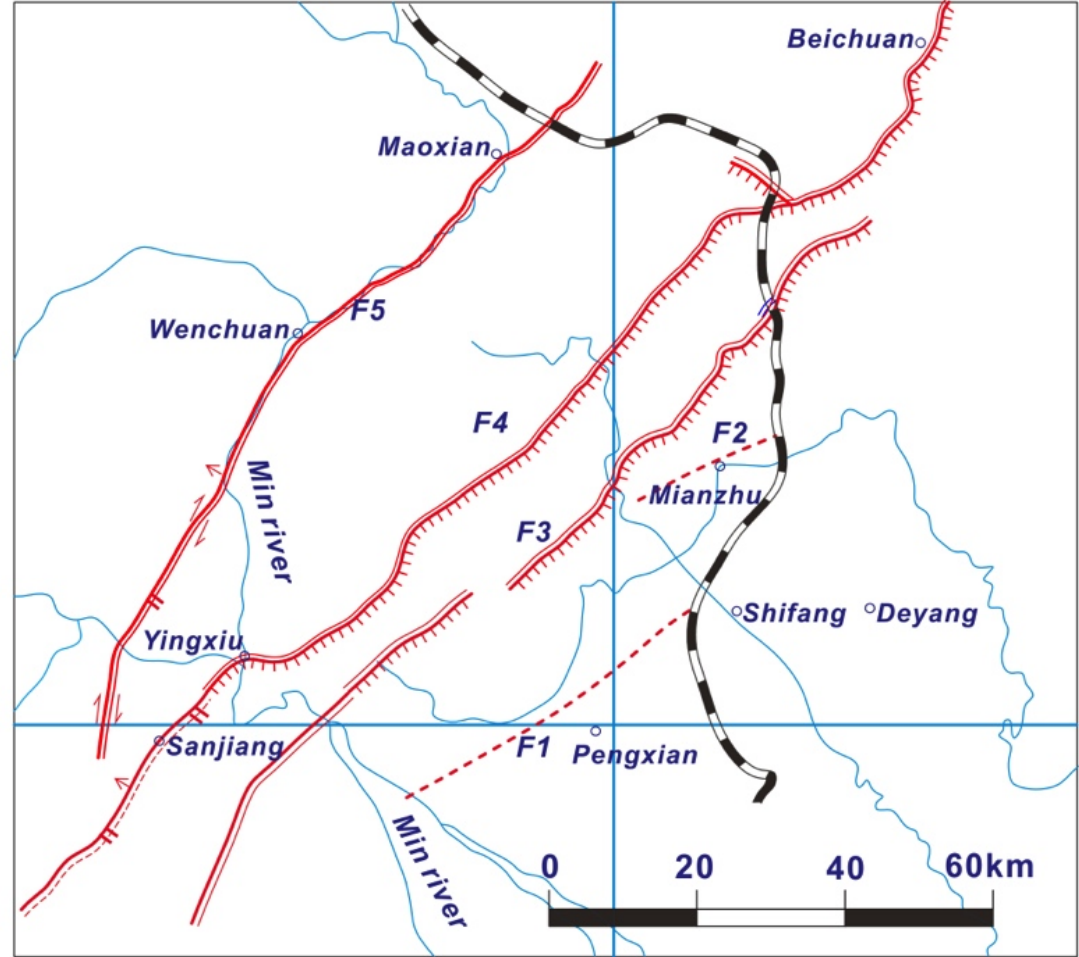

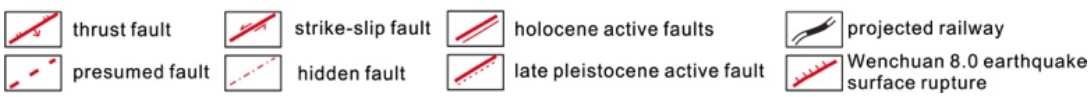

Figure 4 Active faults in the Longmenshan fault zone

F1: Shifang-Banwapu fault; F2: Mianzhu fault; F3: PengxianGuanxian fault; F4: Beichuan-Yingxiu fault; and F5: MaowenWenchuan fault

The Beichuan-Yingxiu fault (F4 in Figure 4), with a total length of up to 240 to $250 \mathrm{~km}$, strikes at $\mathrm{N} 40-60^{\circ} \mathrm{E}$ with dip angles ranging from $45^{\circ}$ to $85^{\circ}$. The fault is a strike-slip fault. It was mainly developed between the strata of Palaeozoic and Mesozoic. The Beichuan-Yingxiu fault is the most significant one within the Longmenshan fault zone, where marked surface fractures was found. According to the historical records, the strongest earthquake before 2008 associated with this fault was the Ms 6.2 Beichuan earthquake in 1958. The ChengLan railway line passes through the Beichuan-Yingxiu fault at the locations near towns, Gaochuan,
Mianzhu, and Jinxi Lake and Anxian. Two branch ruptures extending northeast have been found. The extension of surface rupture at $\mathrm{N} 50-75^{\circ} \mathrm{E}$, appears very clear in Quanshui village of Gaochuan, which cuts the riverbed, slope and roads, and forms a water fall with a falling height of $3.5 \mathrm{~m}$ (Figure 5).

The Maowen-Wenchuan fault (F5 in Figure 4) belongs to the rear section of the Longmenshan fault zone. The general strike of the fault is $\mathrm{N} 30-55^{\circ} \mathrm{E}$ and the dips are from $50^{\circ}$ to $70^{\circ}$ towards the northwest. Since Late Quaternary, the tectonic activities associated with this fault mainly are in the form of 
dextral dislocation. The fault trough was shown in Figure 6. The Maowen-Wenchuan fault has suffered from dextral reverse movement since Late Quaternary. The average slip velocities at both horizontal and vertical directions are $1.0 \pm 0.1$ $\mathrm{mm} / \mathrm{a}$ and the horizontal and vertical displacements are roughly the same. The resultant slip velocity is $1.4 \pm 0.1 \mathrm{~mm} / \mathrm{a}$, on average.

\subsection{Earthquake}

The Longmenshan fault zone is located in the middle part of the famous south-north trending lineament seismic belt in China. Violent earthquakes are mainly concentrated in Tianshui-Wudu-Songpan area and Longmenshan fault zones. An Ms. 8 earthquake, for example, occurred in the south

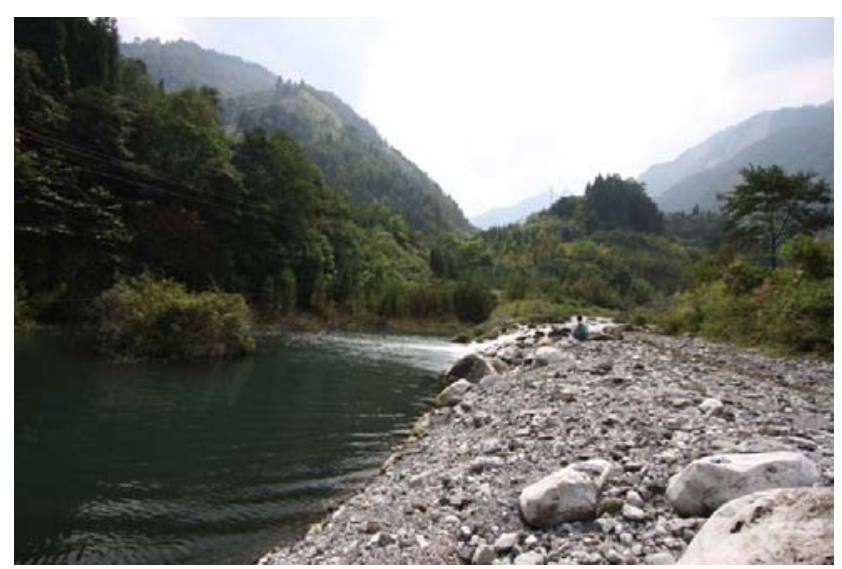

Figure 5 Water fall caused by earthquake rupture in Quanshui village, Gaochuan of Tianshui City, Guansu Province in 1654; An Ms. 8 earthquakes in the south of Wudu City in 1879; Ms. 7 and 7.5 earthquakes in Maoxian County in 1713 and 1933 respectively; An Ms. 7.2 earthquake in SongpanPingwu area in 1976; and the latest Ms. 8.0 earthquakes in Wenchuan, Sichuan province in 2008.

The earthquake records in this seismic belt date back to 193 B.C. From then on, totally 196 earthquakes have been recorded, and none of them is less than Ms. 4.7 (three earthquakes reached Ms. 8; eight reached Ms. 7.0 7.9; and thirty-three reached Ms. 6.0 - 6.9). The largest one with Ms. of 8 occurred in the south of Tianshui City in 1654, south of Wudu in 1879 and Wenchuan in 2008, respectively.

The earthquake events exhibit certain periodicity in the
Longmenshan seismic belt. The first active period lasted roughly for 146 years from 1573 to 1718 inclusive (Table 1, Figure 4). Late on, the fault zone was relatively inactive during years from 1719 to 1878 , with no earthquake exceeding Ms. 7. The second earthquake-active period has lasted for 130 years since 1879 with two Ms. 8, two Ms. 7.0 - 7.9 and fifteen Ms. 6.0 - 6.9 earthquakes. The frequency of earthquake activity is more obvious than the first active period and the total quantity of cumulative strain energy released are also much more than the first period.

Up to date, there seems to be a lack of about 15 years, as the first active period lasted for 146 while the second has just experienced for about 130 so far. It might be estimated that in the future one hundred years, this

Table 1 Earthquake activity of the Longmenshan fault zone

\begin{tabular}{|c|c|c|c|c|c|c|}
\hline \multirow[t]{2}{*}{ Stage } & \multirow[t]{2}{*}{ Seismic activity period division } & \multirow{2}{*}{$\begin{array}{l}\text { Length of } \\
\text { time period }\end{array}$} & \multicolumn{3}{|c|}{$\begin{array}{l}\text { Times of earthquakes of different } \\
\text { magnitudes }\end{array}$} & \multirow[t]{2}{*}{$\mathrm{M}_{\max }$} \\
\hline & & & $6.0-6.9$ & $7.0-7.9$ & $\geq 8.0$ & \\
\hline 1 & $\begin{array}{l}\text { Relatively quiet period (?- 1572) } \\
\text { Relatively activity period }(1573-1718)\end{array}$ & $\begin{array}{l}? \\
146\end{array}$ & $\begin{array}{l}(1) \\
6\end{array}$ & 2 & 1 & $\begin{array}{c}(61 / 4) \\
8\end{array}$ \\
\hline 2 & $\begin{array}{l}\text { Relatively quiet period }(1719-1878) \\
\text { Relatively activity period }(1879-\text { ?) }\end{array}$ & $\begin{array}{l}160 \\
(130)\end{array}$ & $\begin{array}{c}3 \\
(15)\end{array}$ & $\begin{array}{c}0 \\
(2)\end{array}$ & $\begin{array}{c}0 \\
(2)\end{array}$ & $\begin{array}{l}61 / 2 \\
(8)\end{array}$ \\
\hline
\end{tabular}

Note: The numbers in brackets are estimates according to the retrievable records.

Figure 6 Surface dislocation caused by the MaowenWenchuan fault near the railway line

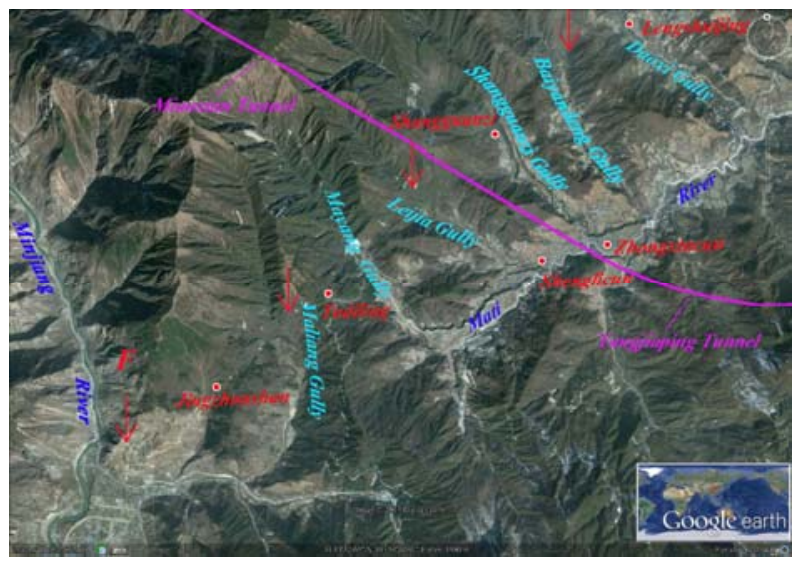


region will be at the last stage of the second active period followed by a relative quiet period. There will also be possible for earthquakes with Ms. 7 or greater to happen in this region, but the general earthquake level should be less than the average since 1879 .

\subsection{Seismic zoning}

On the basis of the evaluation of seismic intensity along the railway corridor, the alignment of Cheng-Lan railway is divided into sections, likely subjected to different levels of earthquake (Table 2). It is found that about $204 \mathrm{~km}$ of the total length of the railway are located in areas with peak ground acceleration of $0.10 \mathrm{~g}$ to $0.15 \mathrm{~g}$, and $257 \mathrm{~km}$ located at areas with $0.20 \mathrm{~g}$.

\subsection{Georisk control for active faults and possible earthquakes}

\subsubsection{Engineering geological principles for route selection}

(1) The railway line should cross the active faults at great intersecting angles to minimize the overlapping of them. A right-angle intersection is the best;
(2) In the case that the railway has to be laid down parallel with active faults, the footwall is preferential and distance from the faults should be guaranteed;

(3) Special structures, for example, large-span bridges, should not stride over active faults directly;

(4) When the railway has to cross the active faults, the antiseismic measures such as engineering grille, pile and retaining wall should be taken for roadbed and its slopes. The freely supported beam with beam falling prevention devices should be taken for bridges. Round or elliptic section should be adopted for tunnels, with a deformation allowance of $30 \mathrm{~cm}$ reserved in both first and second linings. The stepped excavation method with temporary inverted arch should be taken to preventing distortion of tunnel section.

\subsubsection{Route selection}

As the foregoing discussion, a section of $310 \mathrm{~m}$ long of the railway line intersect with five faults in the Longmenshan fault zone at angles of $65^{\circ}-90^{\circ}$. A section of $130 \mathrm{~m}$ long intersects a fault in East Kunlun fault zone at an angle of $70^{\circ}$. A section of 490 long intersects four faults in
West Qinling fault zone at angles of $41-90^{\circ}$. The intersecting angles are all great, together with the anti-seismic engineering measures mentioned above to minimize the risk due to active faults. As shown in Table 3, the railway line has been seated at the footwall and kept as far as possibly away from the active Minjiang fault. Only a section of about $756 \mathrm{~m}$ of the railway is located within a distance less than $200 \mathrm{~m}$ from the fault. The farthest distance is up to $4.3 \mathrm{~km}$ in Maoxian-Songpan section. Besides, all special structure, such as high piers and largespan bridges striding over minor fractures have been arranged as far as possible from active faults as shown in Table 4.

\section{Assessment of Geo- hazards Related to the Wenchuan Earthquake}

\subsection{Landslides}

The Longmenshan section that the railways have to pass through is very sensitive to landslides. Figure 7 shows the distribution of landslides caused by the 2008 Wenchuan earthquake.

The data are from remote sensing interpretation and field

Table 2 Divisions of the railway according to seismic intensity

\begin{tabular}{|c|c|c|c|c|c|}
\hline No. & Range & Distance & Length $(\mathrm{km})$ & PGA (g) & $\mathrm{CP}$ \\
\hline 1 & Chengdu plain section & $\mathrm{DKO}+\mathrm{OOO}-\mathrm{DK} 2 \mathrm{O}+100$ & 20 & 0.10 & $0.45 \mathrm{~s}$ \\
\hline 2 & Mamuhe-Zhishui section & $\mathrm{DK} 20+100-\mathrm{DK} 72+560$ & 52 & 0.15 & $0.40 \mathrm{~s}$ \\
\hline 3 & $\begin{array}{l}\text { Zhishui-Shenxianchi section } \\
\text { (Longmenshan, Mingjiang fault belts) }\end{array}$ & $\mathrm{DK}_{72}+560-\mathrm{DK}_{32} 20+100$ & 248 & 0.20 & $0.45 \mathrm{~s}$ \\
\hline 4 & Shenxianchi-Shangzhang section & $\mathrm{DK}_{320}+100-\mathrm{DK} 450+000$ & 132 & 0.15 & $0.45 \mathrm{~s}$ \\
\hline 5 & Shangzhang-Hadapu section & $\mathrm{DK} 450+000-\mathrm{DK} 459+000$ & 9 & 0.20 & $0.45 \mathrm{~s}$ \\
\hline
\end{tabular}

Note: $\mathrm{PGA}=$ Peak ground acceleration; $\mathrm{CP}=$ Characteristic period of the seismic response spectrum. 
Table 3 Distances between the railway alignment and the Minjiang fault

\begin{tabular}{|c|c|c|c|c|}
\hline No. & Distance from the fault & Alignment section & Section length(m) & Total section length(m) \\
\hline 1 & Less than $200 \mathrm{~m}$ & D3K247+900 D3K248+656 & 756 & 756 \\
\hline \multirow{3}{*}{2} & \multirow{3}{*}{$200-500 \mathrm{~m}$} & D3K246+130 D3K247+900 & 1,770 & \multirow{3}{*}{4,659} \\
\hline & & D3K248+656 D2K249+075 & 419 & \\
\hline & & DK251+675 DK254+145 & 2,470 & \\
\hline \multirow{3}{*}{3} & \multirow{3}{*}{$500-1,000 \mathrm{~m}$} & $\mathrm{DK} 222+820 \sim \mathrm{D}_{3} \mathrm{~K} 239+800$ & 16,980 & \multirow{3}{*}{22,980} \\
\hline & & $\mathrm{D}_{3} \mathrm{~K} 242+73 \mathrm{O} \sim \mathrm{D}_{3} \mathrm{~K} 246+13 \mathrm{O}$ & 3,400 & \\
\hline & & $\mathrm{D} 2 \mathrm{~K} 249+075 \sim \mathrm{DK} 251+675$ & 2,600 & \\
\hline \multirow{4}{*}{4} & \multirow{4}{*}{$1,000-3,000 \mathrm{~m}$} & $\mathrm{D} 8 \mathrm{~K} 148+000 \sim \mathrm{D} 9 \mathrm{~K} 180+880$ & 32,880 & \multirow{4}{*}{55,650} \\
\hline & & D1K196+180 D1K210+ooo & 13,820 & \\
\hline & & $\mathrm{DK} 216+800 \sim \mathrm{DK} 222+820$ & 6,020 & \\
\hline & & D3K239+800 D3K242+730 & 2,930 & \\
\hline \multirow{3}{*}{5} & \multirow{3}{*}{ More than 3,000 m } & $\mathrm{D} 9 \mathrm{~K} 180+880 \sim \mathrm{D} 1 \mathrm{~K} 196+180$ & 15,300 & \multirow{3}{*}{87,100} \\
\hline & & $\mathrm{D} 1 \mathrm{~K} 210+000 \sim \mathrm{DK} 216+800$ & 6,800 & \\
\hline & & DK259+O0O D5K324+Ooo & 65,000 & \\
\hline Total & & & 171,145 & 171,145 \\
\hline
\end{tabular}

Table 4 Summary of bridges on the Cheng-Lan railway and the active faults

\begin{tabular}{|c|c|c|c|c|c|c|c|}
\hline No. & Location & Bridge name & Bridge type & $\mathrm{TL}(\mathrm{m})$ & PGA (g) & BHP & $\begin{array}{l}\text { Lithology of the site and distance to } \\
\text { the fault }\end{array}$ \\
\hline 1 & $\mathrm{D} 2 \mathrm{~K} 76+533$ & $\begin{array}{l}\text { Zhishuihe } \\
\text { double-lane } \\
\text { bridge }\end{array}$ & Continuous beam & 343.99 & 0.20 & 52 & $\begin{array}{l}\text { Lithology: limestone with sandstone } \\
\text { of Xinduqiao group. } \\
\text { Distance: } 275 \text { m to the Pengxian- } \\
\text { Guanxian fault to the left; } 390 \text { m to } \\
\text { the Meirenjiao fault to the right. }\end{array}$ \\
\hline 2 & YDK111+110 & $\begin{array}{l}\text { Yangijgou } \\
\text { bridge }\end{array}$ & Continuous beam & 263.6 & 0.20 & 60 & $\begin{array}{l}\text { Lithology: phyllite of Maoxian group. } \\
\text { Distance: } 19 \mathrm{~km} \text { to the nearest } \\
\text { Loongmenshan central fault. }\end{array}$ \\
\hline 3 & DK333+704. & $\begin{array}{l}\text { Yalong } \\
\text { double-lane } \\
\text { bridge }\end{array}$ & $\begin{array}{l}\text { Simple steel truss } \\
\text { beam }\end{array}$ & 335.43 & 0.15 & 105 & $\begin{array}{l}\text { Lithology: sandstone and slate with } \\
\text { limestone of medium Triassic (T2zg). } \\
\text { Distance: about } 3 \mathrm{~km} \text { to the East } \\
\text { Kunlun active fault. }\end{array}$ \\
\hline 4 & $\mathrm{DK}_{354+232}$ & $\begin{array}{l}\text { Jiuzhaigou } \\
\text { double- } \\
\text { lanebridge }\end{array}$ & $\begin{array}{l}\text { Continuous steel } \\
\text { struture }\end{array}$ & 352.927 & 0.15 & 78 & $\begin{array}{l}\text { Lithology: sandstone with limestone } \\
\text { and slate of Zhagunao group, Triassic } \\
\left(\mathrm{T}_{3} \mathrm{Z}\right) \text {. } \\
\text { Distance: } 16.7 \mathrm{~km} \text { to the East Kunlun } \\
\text { active fault. }\end{array}$ \\
\hline 5 & D6K368+550 & $\begin{array}{l}\text { Duonuohei } \\
\text { river double- } \\
\text { lane bridge }\end{array}$ & $\begin{array}{l}\text { Continuous } \\
\text { simple steel truss } \\
\text { beam }\end{array}$ & $645 \cdot 5$ & 0.15 & 111 & $\begin{array}{l}\text { Lithology: sandstone and slate with } \\
\text { limestone of Zagunao group, Triassic } \\
\left(\mathrm{T}_{3 \mathrm{Z}}\right) \text {. } \\
\text { Distance: } 15 \mathrm{~km} \text { to the East Kunlun } \\
\text { active fault; } 17 \mathrm{~km} \text { to the Diebu- } \\
\text { Bailongjiang fault. }\end{array}$ \\
\hline 6 & DK $417+863.5$ & $\begin{array}{l}\text { Bailongjiang } \\
\text { double-lane } \\
\text { bridge }\end{array}$ & $\begin{array}{l}\text { Bearing type on } \\
\text { reinforced } \\
\text { concrete arch }\end{array}$ & 516.2 & 0.15 & 72 & $\begin{array}{l}\text { Lithology: granite. } \\
\text { Distance: } 9 \mathrm{~km} \text { to the Guanggaishan } \\
\text { fault. }\end{array}$ \\
\hline
\end{tabular}

Note: $\mathrm{TL}=$ Total length; $\mathrm{PGA}=$ Peak ground acceleration; $\mathrm{BHP}=$ Biggest high piers 


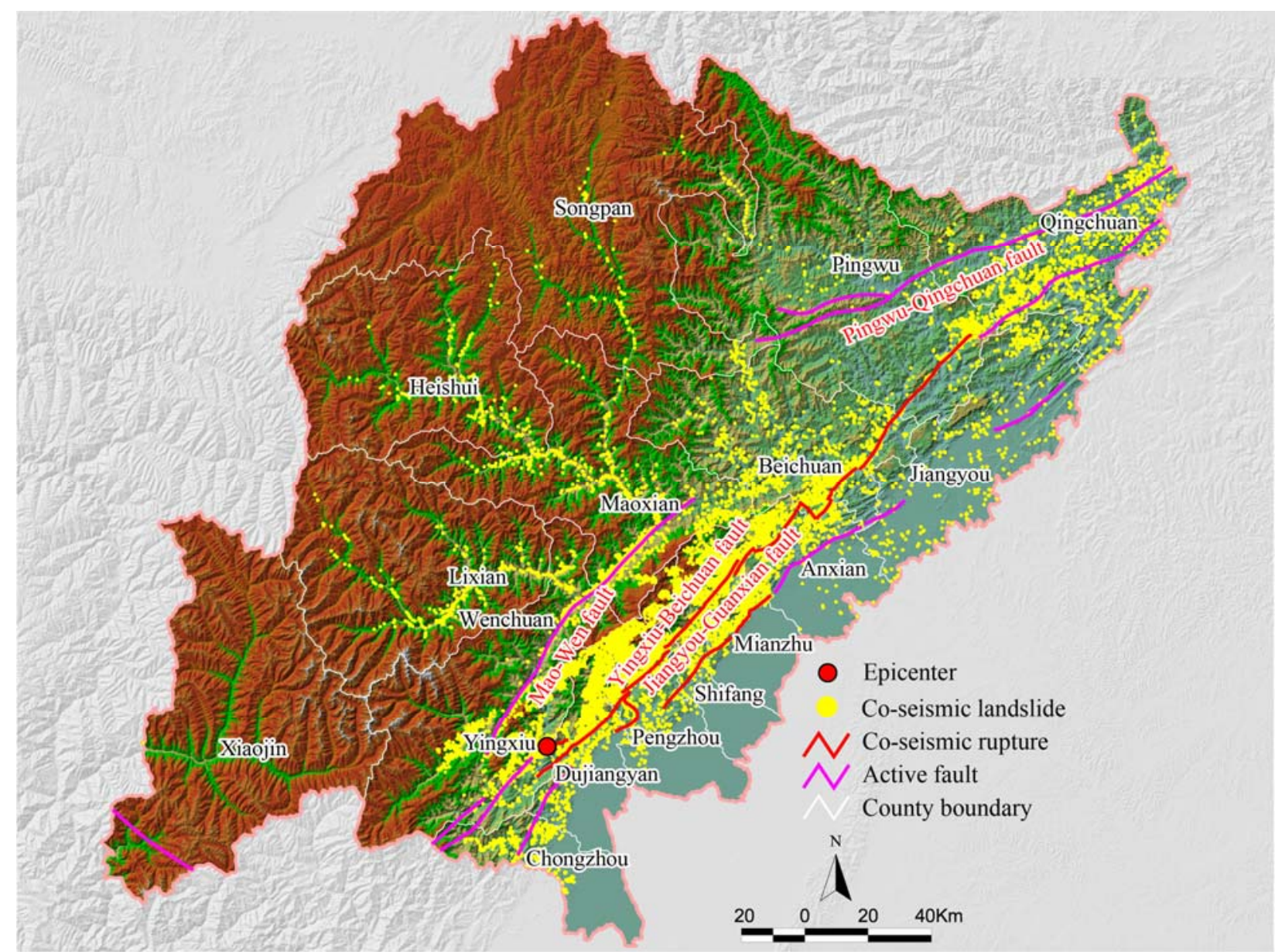

Figure 7 Distribution of landslides caused by the 2008 Wenchuan earthquake (Li et al. 2003)

investigation. It shows that the total number of landslides is about 48,000 in a $60,000 \mathrm{~km}^{2}$ area. The distribution characteristics of the earthquake-induced landslides are given in detail as follows.

(1) As shown in Figure 7, landsides after the Earthquake show zonal distribution along the seismogenic fault. The farther the distance from the seismogenic fault, the smaller the landslide density is. Landslides within $10 \mathrm{~km}$ from the seismogenic fault are the most developed (about 2/3 of the total occurred in this region), with an occurrence density of about 3.5 Nos. $/ \mathrm{km}^{2}$ on average. The landslides density decreases rapidly after $10 \mathrm{~km}$ from the fault. The proposed railway is, therefore, placed with a distance greater than $10 \mathrm{~km}$ from the active fault, in order to avoid damage due to landslides caused by the Wenchuan earthquake (Figure 8). The Black River Bridge, for example, is about $15 \mathrm{~km}$ away from West Qinling fault zone and about $17 \mathrm{~km}$ away from Diebu-Bailongjiang fault zone.

(2) The distribution of landslides induced by the earthquakes has obvious "hanging wall/footwall" effect (Huang and Li 2008 \& 2009), as the landslide density in the hanging wall of fault is significantly greater than that in the footwall.

(3) Landslide distribution has significant terrain effect. Most landslides are located in slopes with gradients ranging from $25^{\circ}$ to $50^{\circ}$. About $70 \%$ of the landslides are distributed in such areas. It means the railway lines should avoid steep slopes and be arranged in gentle slope area. In addition, the earthquake-induced landslides usually occur in such areas as the turning parts of a slope, thin mountain ridge, isolated hills with free faces, as seismic waves have a significant amplification effect in these areas. 
(4) The landslide distribution also exhibits significant "direction" effect, as landslides are very much developed in slopes dipping at the propagation direction of seismic waves.

\subsection{Debris flows}

Based on field investigation, there were 77 typical debris flows developed along the railway alignment, 27 of which have potential effect on the proposed railway. Debris flows mainly distribute in five areas, Anxian, Maoxian, Songpan, Jiuzhaigou, and Lazikou. Most of them are developed in valleys. Valley-type debris flows are normally closely associated with climate, and happen frequently from May to September. The debris flows are formed in middle mountain landform, and the elevation difference is about $1000 \mathrm{~m}$. The longitudinal slope of the valley beds is about $300 \%$. Both sides of the mountains show deep cutting with slope gradients greater than $40^{\circ}$. The debris flows in Anxian region are located in the area of the Wenchuan earthquake. It is very typical of post-earthquake debris flows triggered by heavy rainfall.

The debris flows in Maoxian and Songpan areas is linearly distributed along two sides of the Minjiang River. The debris flows in Jiuzhaigou and Lazikou areas are of small or medium size. The density of debris flows is low. In these areas, the faults have no significant activities in the last century, with few debris flow occurrences. Therefore the

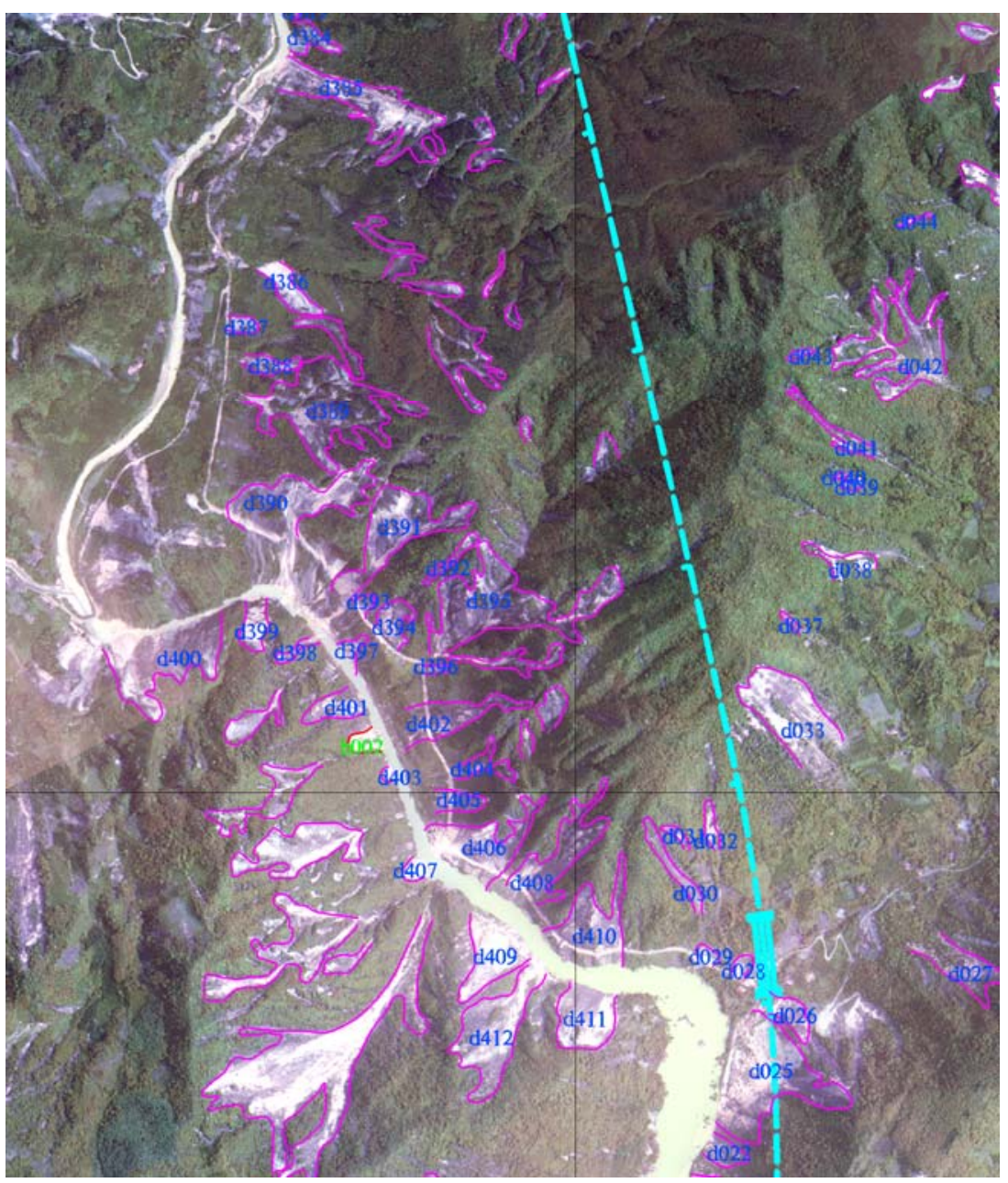

Figure 8 The route selection to avoid landslides

proposed railway route is appropriate in general, with construction sites in suitable areas account for $59.4 \%$ of the total line, and the basically appropriate area account for $40.6 \%$ of the total length.

\subsection{Georisk control of landslide and debris flow}

(1) Even though there are about 48,000 landslides in the affected area of the Wenchuan earthquake, only 444 landslides is within $1 \mathrm{~km}$ of the railway line. In order to avoid influences by these landslides, deep-buried, long tunnels are suggested when crossing the Longmenshan mountain. The length of tunnels and bridges counters for $95 \%$ of the railway length in this area. The railway line meets 8 landslides in this area (Table 5), and engineering measures have been employed for controlling their stability.

(2) Extraordinary floods, debris flows, and barrier lakes possibly caused by upstream landslides are taken into account when the bridges crossing valley are designed, so as to leave enough space for minimizing the risk caused by these potentials. 
Table 5 Major landslides along the railway line

\begin{tabular}{|c|c|c|c|}
\hline Location & Name & $\begin{array}{l}\text { Engineering geological } \\
\text { characteristics }\end{array}$ & Engineering impact evaluation \\
\hline $\begin{array}{l}\mathrm{D} 2 \mathrm{~K} 110+400 \\
- \\
\mathrm{D} 2 \mathrm{~K} 110+980\end{array}$ & $\begin{array}{l}\text { Longmenshan } \\
\text { tunnel exit }\end{array}$ & $\begin{array}{l}\text { Length of about } 800 \mathrm{~m} \text {, width of } 500 \\
\text { m and thickness of about } 30 \mathrm{~m} \text {. } \\
\text { Currently stable; may be unstable } \\
\text { under heavy rains. }\end{array}$ & $\begin{array}{l}\text { Great impact on the line. } \\
\text { Retaining wall and supporting piles } \\
\text { are recommended. }\end{array}$ \\
\hline $\begin{array}{l}\mathrm{D} 8 \mathrm{~K} 151+560 \\
- \\
\mathrm{D} 8 \mathrm{~K} 151+680\end{array}$ & $\begin{array}{l}\text { Longtang two- } \\
\text { lane bridge }\end{array}$ & $\begin{array}{l}\text { Currently at the limit balance; } \\
\text { cutting in the front part should be } \\
\text { avoided for laying down the railway. }\end{array}$ & $\begin{array}{l}\text { It is currently at the limit balance } \\
\text { state. Cutting in its front part should } \\
\text { be avoided. }\end{array}$ \\
\hline $\begin{array}{l}\text { DK203+895 } \\
- \\
\text { DK203+960 }\end{array}$ & $\begin{array}{l}\text { Zhenjiangguan } \\
\text { Station }\end{array}$ & $\begin{array}{l}\text { Length of about } 115 \mathrm{~m} \text {, width of } 75 \\
\mathrm{~m} \text {, and thickness of about } 5-20 \mathrm{~m} \text {. }\end{array}$ & $\begin{array}{l}\text { Great impact on the railway line. } \\
\text { Retaining wall and supporting piles } \\
\text { are recommended. }\end{array}$ \\
\hline $\begin{array}{l}\text { DK204+200 } \\
- \\
\text { DK204+250 }\end{array}$ & $\begin{array}{l}\text { Zhenjiangguan } \\
\text { Station }\end{array}$ & $\begin{array}{l}\text { Length of about } 70 \mathrm{~m} \text {, width of } 6 \mathrm{om} \\
\text { and thickness of } 5-15 \mathrm{~m} .\end{array}$ & $\begin{array}{l}\text { Great impact on the line. Retaining } \\
\text { wall and supporting piles are } \\
\text { recommended. }\end{array}$ \\
\hline $\begin{array}{l}\text { D3K239+632 } \\
- \\
\text { D3K239+777 }\end{array}$ & $\begin{array}{l}\text { Songpan tunnel } \\
\text { entrance } \\
\text { ancient landslide }\end{array}$ & $\begin{array}{l}\text { Thickness of } 5-30 \mathrm{~m} \text { thick, with a } \\
\text { volume of } 83 \times 10^{4} \mathrm{~m}^{3} \text {. }\end{array}$ & $\begin{array}{l}\text { Construction could easily cause } \\
\text { reactivation of it. } \\
\text { Reinforcements are recommended. }\end{array}$ \\
\hline $\begin{array}{l}\mathrm{DK} 350+920 \\
- \\
\mathrm{DK} 351+600\end{array}$ & Jiuzhaigou Station & $\begin{array}{l}\text { Length of } 1000 \mathrm{~m} \text {, width of } 564 \mathrm{~m} \\
\text { and thickness of } 20-50 \mathrm{~m} .\end{array}$ & $\begin{array}{l}\text { Excavation would cause collapse and } \\
\text { local instability. Reinforcement is } \\
\text { recommended. }\end{array}$ \\
\hline $\begin{array}{l}\mathrm{D} 6 \mathrm{~K} 367+490 \\
- \\
\mathrm{D} 6 \mathrm{~K} 368+406\end{array}$ & Heihe Bridge & $\begin{array}{l}\text { Width of } 250-530 \mathrm{~m} \text { and thickness } \\
\text { of } 10-55 \mathrm{~m} \text {. The total volume is } \\
\text { about } 2544 \times 10^{4} \mathrm{~m}^{3} \text {. }\end{array}$ & $\begin{array}{l}\text { Pier construction may cause local } \\
\text { slope instability. } \\
\text { Enhanced measures are } \\
\text { recommended. }\end{array}$ \\
\hline
\end{tabular}

(3) A systematic monitoring for landslides and debris flows has been designed for the entrance and exit of each tunnel.

\section{Assessment of Impact of Earthquake on Tunnels}

The Wenchuan earthquake showed that the effect of the vibration intensity on the tunnel structure is less than that on the surface building. This suggests that priority should be given to tunnels rather than bridges in areas with high peak ground acceleration. The tunnel projects should be feasible by strengthening tunnel portal and entrance structures, strictly controlling the height of cutting slope of the tunnel entrance, and taking appropriate antiseismic measures.

\subsection{Geostress}

As the forgoing discussion, the tectonic situation in the project area is complex. The regional stress is mainly composed of the NW-SE compressive stress produced by the SE movement of the plateau. The direction of the maximum horizontal stress in the southern section of the railway (DK10o $\mathrm{DK} 260$ ) is $\mathrm{N} 20-75^{\circ} \mathrm{W}$, and it is the same as the regional tectonic stress (Figure 9). The direction of the maximum horizontal stress in the northern section (DK260 - DK400) is $\mathrm{N}_{20}^{\circ} \mathrm{E}-$ $\mathrm{N} 48^{\circ} \mathrm{W}$.

According to the in-situ measurements, the maximum horizontal stress is from 8.8 MPa to $9.5 \mathrm{MPa}$ at the depth of $500 \mathrm{~m}, 13.8 \mathrm{MPa}-14.5 \mathrm{MPa}$ at $700 \mathrm{~m}$, and $18.8 \mathrm{MPa}-20.7$ $\mathrm{MPa}$ at the depth $1000 \mathrm{~m}$. Along the railway line, the horizontal stress in sections from the Longmenshan fault zone to Minjiang fault zone is relatively high. The horizontal tectonic stress from Chengdu plain and the Yellow River in the north of Qinling is relatively low. The maximum horizontal principal stress in the project area is NWdirection. However, because the internal stress become lower and the edge stress increases, the maximum principal stress from both sides of the faults tends to parallel to the faults. The horizontal tectonic stress in the project area is varied. Lateral pressure coefficient ranges from 1.02 to 1.77 , with an average of about 1.33 .

The tectonic stress in the fault zone is significantly reduced, but the gravity stress and lateral pressure is essentially unchanged. The 
strata on both sides of the fault will produce a greater stress concentration. There will be a significant stress concentration at the ends of the fault, and some discontinuous "rock bridge" of the fault and other parts. Because the internal stress becomes lower and the edge stress increases, the direction of maximum principal stress from both sides of the faults tends to parallel the fault.

\subsection{Characteristics of shattered rockmass and evaluation of its influence on tunnels}

Through a typical shattered mountain which was produced by the Wenchuan earthquake, and a highway tunnel is just completed, we can get the following understandings to the engineering geological properties of shattered rockmasses: shattered rock is the rock with more developed discontinuity and worse interlayer bonding due to the strong earthquake. Hard rock will generate centralized tension cracks. And loosened and soft rock mass leads to volumetric relaxation deformation.

The shattered rock is greatly influenced by the topography, lithology, hydrogeology, and earthquake ground motion and other factors. It's more developed on the upper slopes, especially at the area of long-strip steep ridge, which is often obviously influenced by the amplifying effect of the earthquake acceleration. The area full of the long-strip steep ridge is often larger, and the shattered cracks along the

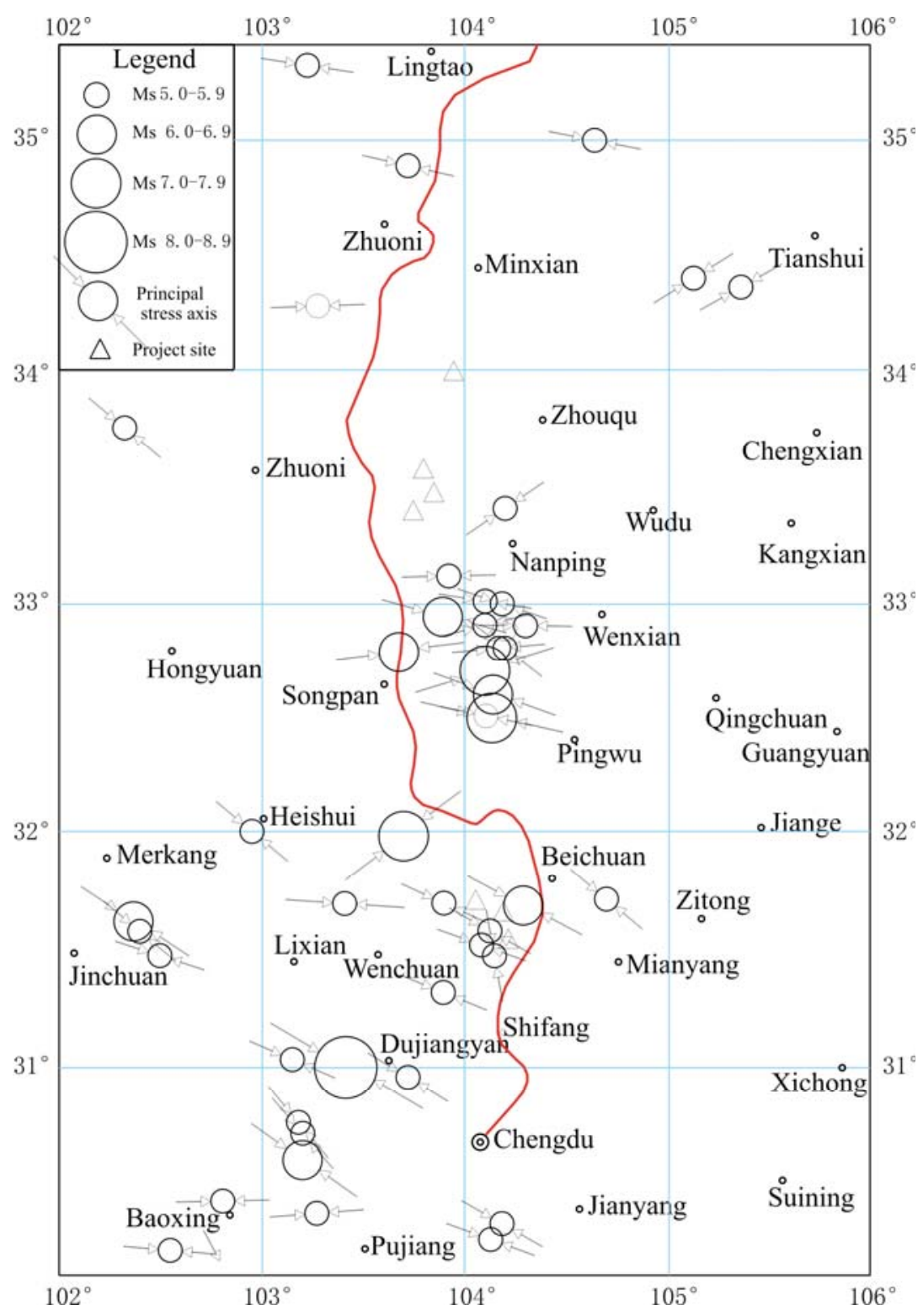

Figure 9 Principal stresses in the study area

ridges are longer.

In severely damaged areas of the Wenchuan earthquake, the field investigation of the shattered rocks surrounding tunnels with hard rocks under construction shows that hard rock has obvious dynamic response in earthquake waves, and it is easy to generate centralized tensile or shear failure in the portal section, which leads to the development of earthquake fissures. The impact of earthquakes on cracks in two ways: 1) the earthquake makes the rock tunnel generate a new fracture; and 2) in the earthquake, original cracks expand or open. Cracks in the shattered rocks deteriorate the integrity of rocks, and often favor the infiltration by groundwater and gas. 


\subsection{Georisk control for tunnels}

\subsubsection{Engineering countermeasures for active faults}

For the tunnels directly passing across the active faults, a variety of factors should be considered to choose a favorable intersection point. A favorable site to facilitate repair and rescue should be chosen. The railway crossing active faults in this area had some successful examples, such as Longxi tunnel in Dujiangyan-Wenchuan highway, which passes through the Longmenshan seismogenic fault.

The Longxi tunnel, located in the Wenchuan earthquake epicenter, is $3658 \mathrm{~m}$ long. The entrance is located in the left bank of the Longxi River, Dujiangyan and the exit located in Yingxiu town. The tunnel has been finished before the earthquake, with linings completed. A tunnel damage investigation after the earthquake indicated that the entrance and exit parts of the tunnel and lining segment near the active faults were severely damaged while the other lining remained essentially intact.

A study led by Prof. Tianbin Li from State Key Laboratory of Geohazard Prevention and Geoenvironment Protection (SKLGP), Chengdu University of Technology, China (Li 2011) thinks that the rock masses destruction is caused by the effect of elastic waves on the free surface. If a tunnel is small, it cannot provide enough free space to produce this effect. It also resulted that the displacement of active faults in the deep rock is much smaller than that on the surface. The earthquake displacement of the active fault in Longxi tunnel is less than $10 \mathrm{~cm}$ (Figure 10). If the entrance and exit of the tunnel are designed at the foot of a slope passing through the active faults, the slope effect of elastic waves will be greatly reduced. Therefore, even under the impacts of "5.12" Wenchuan 8.0 earthquake, most tunnels show their excellent performance to strong earthquakes, the tunnels of Cheng-Lan railway project through the active fault zone are feasible.

In the lining design along the active fault the main problem is the resistance to earthquake damage, and keeping patency after the earthquake is also considered. The tunnel in the line passes through active faults, whose branches have been broken several times in history. Shiziyuan tunnel and Longmenshan tunnel passed through the Longmenshan fault. The tunnel passing through active faults by changing the lining profile and appropriate supporting is improved. A circular lining profile is used and set the allowable deformation to be $30 \mathrm{~cm}$. Anchor arch wall system is employed with the spacing $0.8 \mathrm{~m} \times 0.8 \mathrm{~m}$ (ring $\times$ vertical). The arch part uses ø25 hollow arch anchor of $6 \mathrm{~m}$ long and G32-type anchor of $8 \mathrm{~m}$ long. $10 \mathrm{~m}$ spacing in the active faults lining is reserved to improve the ability and fit the deformation.

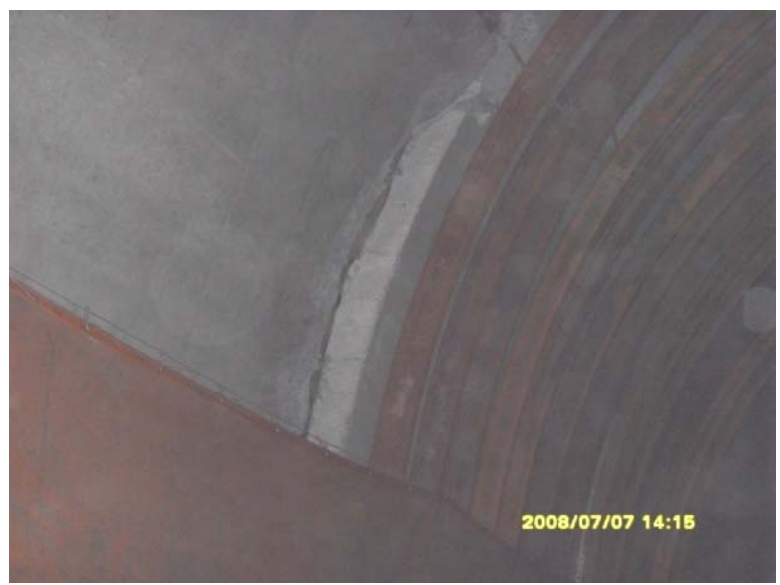

Figure 10 Lining structure damage observed in the Longxi tunnel

\subsubsection{Engineering countermeasure for shattered rockmass}

Investigation of restoration and reconstruction in the earthquake-hit area shows that the engineering treatment of shattered rock should be strengthened. During the hard rock tunnel construction, more attention should be paid to the loose cracks so to avoid the tunnel collapse. To the soft-rock tunnel the wall rock should also be supported to avoid relaxation and large deformation and even collapse. For slightly shattered rock, as it has a little effect on the stability of the surrounding rock the lining thickness may increase.

For moderately shattered rock adversely affects the stability of the surrounding rock, we should upgrade the support measures according to the rockmass grades. Increasing bolt length, grouting and other measures are needed to improve the physical and mechanical properties. For strongly shattered rock have a negative impact 
on the stability, appropriate support measures are taken according to the adjusted wall rock grade.

The tunnel entrance and the shallow slope surface suffer from the amplification effect of seismic wave. The dynamic response of the lining is larger. Shattered rock is also more complex, and seriously damaged. Therefore, earthquake resistance protection for the tunnel entrance should be carefully considered. For the broken strata we take the grouting reinforcement. It is necessary to set damping layer and other antidamping measures to reduce the dynamic response of the lining to avoid large-scale damage.

\subsubsection{Engineering measures for high geostress}

According to the stress tests of the linings, combined with the mechanical parameters of the surrounding rocks, we can determine the possible locations where large deformation and rock burst occur. Through studying similar projects, we developed treatment measures dealing with high geostress, which would be encountered during construction of the railway.

(1) For the regions where anticline and small folds occur, V-type composite lining is used to strengthen the supporting appropriately. And the amount of deformation should be permitted to increase to $15 \mathrm{~cm}$. Anchor arch wall system is designed with spacing $1.0 \mathrm{~m} \times 1.0 \mathrm{~m}$ (ring $\times$ vertical). ø25 hollow arch anchor with $3 \mathrm{~m}$ long is employed for the arch part, and G32-type anchor with $4 \mathrm{~m}$ long for sidewalls. Reinforced concrete is used for secondary lining. Thickness of the arch wall is set $45 \mathrm{~cm}$.

(2) According to geological data we can speculate the fault location. By changing the lining profile and adjusting appropriate supporting measures the stability can be improved. The oval lining profile is set, and the amount of deformation is permitted to be $20 \mathrm{~cm}$. Anchor arch wall system is employed with spacing of $0.8 \mathrm{~m} \times 0.8 \mathrm{~m}$ (ring $\times$ vertical). The arch parts employ ø25 hollow arch anchor of $6 \mathrm{~m}$ long, and G32-type anchor of $8 \mathrm{~m}$ long is used for sidewalls. Thickness of the arch wall is $45 \mathrm{~cm}$.

(3) For the proven fault, by changing the lining profile and adjusting appropriate supporting measures the slopes could be strengthened. The oval lining profile is adopted, and the amount of deformation is permitted to be $25 \mathrm{~cm}$. Anchor arch wall system is adopted with spacing of $0.8 \mathrm{~m} \times 0.8$ $\mathrm{m}$ (ring $\times$ vertical). The arch parts use $\varnothing 25$ hollow arch anchor of $4 \mathrm{~m}$ long, and G32-type anchor of 6 $\mathrm{m}$ long is employed for sidewalls. Thickness of the arch wall is permitted to be $50 \mathrm{~cm}$.

\section{Conclusions}

The Cheng-Lan railway passes through an extremely geologically active area, which is characterized by sharply contrasted topography, low quality of rock masses, active neotectonic status and strong earthquake backgrounds. This study discusses in detail the geological aspects for route selection of the railway and outlines the countermeasures for georisk control. Main conclusions are made as follows.

(1) Generally, one of the essential points to guarantee successful implantation of linear engineering, like railway, in West China is to precisely assess engineering geological conditions along the engineering line and to identify the possible georisks, so that the railway can be laid down in a safe environment. Engineering geological assessment has been carried out during the proposal stage and will be continued in parallel with the construction.

(2) Basically, the general alignment of the railway mainly depends on the regional tectonic features. Geohazards such as landslides, rockfalls and debries flows dominate both the route selection of the railway and the engineering structures (e.g., tunnels or bridges) adopted. Avoiding possible georisks by keeping far away from these geohazards or minimizing the interface with them is a vital practical principle for linear engineering in geologically active area.

(3) In the case where avoiding geohazards is impractical, necessary protection measures should be taken to engineering slopes in high earthquake intensity areas, especially the area with earthquake of Ms. 8 or greater.

(4) The Wenchuan earthquake brought us lessons and experiences for engineering in geologically active area. Attention and consideration, both practical and academic, put on this disaster event will not only help with the home reconstruction, but also prepare us for mitigating and fighting with the future disasters. 


\section{Acknowledgment}

The authors would like to express their great thanks to all persons involved in the field investigation and data preparation of this project. This work was supported by a grant from the Major State Basic Research Development Program of

\section{Reference}

Chen $\mathrm{CH}$, Li B (2006) Geohazard risk assessment for small hydroelectric power stations - A case study of a construction site in Meiniduo River, Yunnan Province. Chinese Journal of Geological Hazard and Control 17(3): 66-72.

Du YB, Yuan CB, Wang YD (2012) Major Geological Hazard and Geological Alignment of Chengdu - Lanzhou Railway. Journal of Railway Engineering Society 8: 11-15.

Gao XH, Qi FQ, Feng J (2012) Application of geohazard risk assessment in the shallow-sea oil-gas development area of liaodong bay. Marine Geology Frontiers 2: 18-26.

Huang RQ, Li WL (2008) Analysis of the geo- hazards triggered by the 12 May (2008) Wenchuan Earthquake in China. Bulletin of Engineering Geology and the Environment 68(3): 363-371. DOI: 10.1007/s10064-009-0207-0.

Huang RQ, Li WL (2009) A Study on the Development and Distribution Rules of Geo-hazards Triggered by the 5.12 Wenchuan Earthquake. Science in China (Series E)Technological Sciences 52(4): 810-819.

Li TB (2011) Damage to mountain tunnels related to the Wenchuan earthquake and some suggestions for aseismic tunnel construction. Bulletin of Engineering Geology and the
China (973 Program) (Grant No. 2013CB733202) and the team research fund of the State Key Laboratory of Geohazards Prevention and Geoenvironment Protection (Grant No. SKLGP).

Environment. DOI: 10.1007/s 10064-011-0367-6.

Li Y, Allen PA, Densmorel AL, Xu Q (2003) Evolution of the Longmen Shan Foreland Basin (Western Sichuan, China) during the Late Triassic Indosinian Orogeny. Basin Research 15: 117-138. DOI: 10.1046/j.1365-2117.2003.00197.x.

Li YR, Aydin A, Xiang XQ, Ju NP, et al. (2012) Landslide susceptibility mapping and evaluation along a river valley in China. Acta Geologica Sinica 86(4): 1022-1030. DOI: 10.1111/j. 1755-6724.2012.00726.x.

Qing SH, Huang RQ, Li D, Jiang LW (2006) Railway location in a mountainous environment in areas of active structures. Journal of Geomechanics 12(2): 243-251. DOI: 10.3969/j.issn. 1006-6616.2006.02.018.

The Second Survey and Design Institute of China Railways (2010) Engineering Geological Assessment Report of Chengdu-Lanzhou Railway.

Zhou CJ, Wu ZH (2011) The characteristics of geothermal field along the Dali-Ruili railway in Western Yunnan Province and their implications for geo-engineering. Geological Bulletin of China 31(3): 326-336. DOI: 10.3969/j.issn.1671-2552.2012. 02.016. 